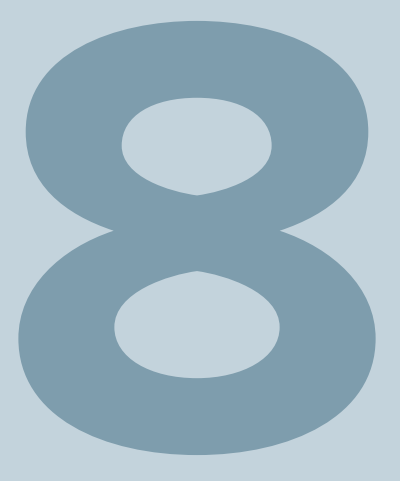

Assessing democratic quality and renewing the potential for democratic advance

8.1 The UK's recent democratic gains and losses

8.2 Counteracting democratic decay...... 



\section{Assessing democratic quality and renewing the potential for democratic advance - Patrick Dunleavy}

When people must live subject either to the power of a controlling opponent, or to the weight of institutions accumulated in history, they experience outcomes that are 'determined, objective, and an already fixed projection of the past'. Powerless people have 'a future poor in alternatives', as the German social theorist Niklas Luhmann put it. For the part of the British public that in 2016 chose to 'take back control' both from the EU, and from the 'globalising' elites of the main UK parties, such considerations seemed remote. Yet the post-history of the Brexit vote has shown that breaking free in any long-experienced context is a complex business. How much more is that also true of a whole political system, where citizens and elites alike are struggling to live up to and evolve liberal democratic ideas, while yet maintaining an effective system of government and valued inherited institutions.

This final part has two main tasks. The first is to give an overall assessment of the UK's changing liberal democracy, looking across all the areas covered in the preceding chapters. The second involves standing back and drawing some wider-out implications - around the loss of a previously influential 'Europeanisation' narrative, the roles of micro-institutions, and the sheer difficulty of achieving a sustainable democratic state. 


\section{1}

\section{The UK's recent democratic gains and losses}

In the 2012 Democratic Audit, the immediate predecessor of this volume, Stuart Wilks-Heeg and colleagues wrote that: 'Democracy is not an "end state". Few would argue that the UK is already as democratic as it would be possible, or desirable to be'. Yet their assessment then was broadly positive on the central components of the UK's polity. They recorded improvements in most aspects of democratic operations since two Audits in the previous decade, despite the adverse impacts of austerity measures that were already emerging following the onset of the great financial crisis in 2008 and the 2010 election.

In particular, although the UK in 2012 had a 'hung' parliament (as it does now), the smooth formation of a Conservative-Liberal Democrat coalition (with a clear majority of MPs in the Commons and of votes at the $\mathbf{2 0 1 0}$ general election) meant that little changed from 'business as usual'. The core institutions of government in Parliament/Westminster and the Cabinet/Whitehall apparently went on operating in ways that showed some remarkable continuities with the Blair-Brown governments that came before them. A coalition agreement seemed almost as 'effective' and able to grapple with hard choices as traditionalists had always claimed single-party majority governments to be.

Today, after the populist upsurge of diffuse discontent captured in the Brexit referendum, the dramatic loss of the May government's majority a year later, and the protracted, lagging and trouble-prone efforts to devise a basis for the UK to leave the European Union, it is the core institutions over which hang the greatest question marks. The poor ability of the party system to cope with Brexit; the inability of May or Corbyn to foster cross-party co-operation in Parliament to develop or steer through anything other than a partisan strategy for Brexit; and the continuation of high levels of political uncertainty around the issue that two-thirds of the public rate as in the top three for importance - all these have created an almost unique period of ineffectiveness and fraught deadlock at the centre of UK government.

Elsewhere in the UK system there have been some important positive developments for liberal democracy. Devolution changes and the growth of civic nationalism in Scotland; a modernisation/ liberalisation of social attitudes around gender, race and identities; and a greater questioning of 'established' institutions that covered up wrongdoing - these have all signalled important extensions of the 'liberal' component of liberal democracy across 
mainland Britain (but less so in Northern Ireland). Yet these changes cannot compensate for the critical failures around the core.

To summarise the conclusions of our analysis, Figure 1 lists a whole series of areas that are important for assessing the democratic quality of any political system. The middle column here shows these key aspects and issues, roughly in the same sequence as the chapters in Parts 1 to 7. For each heading, in the two rightmost columns we show our answers to this qualitative question: 'Have positive and substantial pro-democratisation trends occurred?' And in the two leftmost columns we show our answer to the question: 'Have substantial threats or problems to democratic quality emerged in this area?' Obviously the ideal situation for liberal democratic advance would be one where there have been clear advances, and no worrying adverse trends to offset them. Yet this is not a commonly occurring situation. Instead in most topic areas Figure 1 shows that there is a far more mixed picture, with some positive developments and other adverse changes occurring at the same time.

In order to tie down these judgements more firmly, we borrow a technique from an approach in social science called 'qualitative comparative analysis' (QCA) - but here used to look across many aspects of one big case. One key QCA step is to ask relatively complex and qualitative questions, such as those at the top of Figure 1, but then provide answers using numeric codes to try to firm up and to systematise the judgements involved. There are many sophisticated ways of doing this in QCA, but we have used the simplest which focuses on a five-point scale:

\begin{tabular}{|r|l|}
\hline Number score & Which means: \\
\hline 1.0 & Clearly Yes to the question posed \\
\hline 0.75 & Tending towards Yes \\
0.5 & Impossible to say Yes or No to the question - indeterminate \\
\hline 0.25 & Tending towards No \\
\hline 0 & Clearly No to the question posed \\
\hline
\end{tabular}

(Another way of framing this coding scheme in a comparative way might be to ask for each aspect if the UK falls into the set of countries that show positive developments towards greater democracy, or into the set of countries showing signs of democratic backsliding or decay?) We show the code for positive developments on the right of each topic heading as a green-shaded cell that has one of the five values above. And we show the code value for adverse trends on the left of the topic heading. At the right end of each row we briefly list the positive developments that give rise to the green score. And at the left end of each row we list the changes that explain the pink-shaded problems and threats score. 


\section{Figure 1: Positive developments and adverse developments for aspects of the UK's democracy}

\begin{tabular}{|c|c|c|c|c|}
\hline $\begin{array}{r}\text { Have substantial threats } \\
\text { or problems to democratic } \\
\text { quality emerged in this area? }\end{array}$ & $\begin{array}{l}\text { Problems/ } \\
\text { threats } \\
\text { score }\end{array}$ & $\begin{array}{l}\text { Institutional } \\
\text { or topic area }\end{array}$ & $\begin{array}{l}\text { Gains/ } \\
\text { positives } \\
\text { score }\end{array}$ & $\begin{array}{l}\text { Have positive and } \\
\text { substantial pro- } \\
\text { democratisation trends } \\
\text { occurred in this area? }\end{array}$ \\
\hline $\begin{array}{l}\text { - Under plurality rule local and } \\
\text { regional levels of deviation } \\
\text { from proportionality (DV) } \\
\text { are still high. And 'electoral } \\
\text { deserts' are widespread. } \\
\text { - The historical record and } \\
\text { political science theory both } \\
\text { predict higher national DV if } \\
\text { multi-party politics revives. }\end{array}$ & 1 & $\begin{array}{l}\text { Voting } \\
\text { system } \\
\text { fairness } \\
\text { across } \\
\text { parties }\end{array}$ & 0.5 & $\begin{array}{l}\text { - National deviation from } \\
\text { proportionality (DV) scores fell } \\
\text { in } 2017 \text {, making the result the } \\
\text { most proportional for more } \\
\text { than two decades. But this } \\
\text { was highly contingent on four- } \\
\text { fifths of voters backing the top } \\
\text { two parties. }\end{array}$ \\
\hline $\begin{array}{r}\text { - The obsolescence and } \\
\text { ineffectiveness of UK electoral } \\
\text { integrity laws are apparant for } \\
\text { digital campaigning and the } \\
\text { social media era. } \\
\text { - Possible Russian influence in } \\
\text { the Brexit referendum. } \\
\text { - Failure to control 'Leave' } \\
\text { campaign over-spending. }\end{array}$ & 0.75 & $\begin{array}{c}\text { Electoral } \\
\text { integrity and } \\
\text { participation }\end{array}$ & 0.75 & $\begin{array}{l}\text { - Turnout improved in } 2017 \text {, } \\
\text { and at the } 2016 \text { Brexit } \\
\text { referendum. } \\
\text { - The age gap in turnout was } \\
\text { reduced in } 2017 \text { and youth } \\
\text { participation increased. }\end{array}$ \\
\hline $\begin{array}{r}\text { - Procedures for electing party } \\
\text { leaders in the Conservatives } \\
\text { and Liberal Democrats in } \\
2016-18 \text { were short-circuited } \\
\text { in ways that meant party } \\
\text { members never got to vote on } \\
\text { choosing a leader. } \\
\text { - The inability to arrange a } \\
\text { political succession to Theresa } \\
\text { May, and some of Corbyn's } \\
\text { problems from his MPs and the } \\
\text { press, show that the legitimacy } \\
\text { of members electing party } \\
\text { leaders is still widely impugned. }\end{array}$ & 0.5 & $\begin{array}{l}\text { The } \\
\text { democratic } \\
\text { roles of } \\
\text { political } \\
\text { parties }\end{array}$ & 0.75 & $\begin{array}{l}\text { - Party memberships have } \\
\text { grown strongly in the Labour } \\
\text { Party and SNP. } \\
\text { - Mass memberships and } \\
\text { 'clicktivism' via social media } \\
\text { both seem to have fostered } \\
\text { more member and supporter } \\
\text { participation. }\end{array}$ \\
\hline $\begin{array}{l}\text { - Powerful business lobbies } \\
\text { are still overtly obstructing } \\
\text { action against evident harms, } \\
\text { as with pollution from diesel } \\
\text { cars, sugar in food and an } \\
\text { obesogenic environment. }\end{array}$ & 0.5 & $\begin{array}{l}\text { The interest } \\
\text { group } \\
\text { process }\end{array}$ & 0.5 & $\begin{array}{l}\text { - A process more focused on } \\
\text { cognitive competition may be } \\
\text { developing. }\end{array}$ \\
\hline $\begin{array}{r}\text { - The partisan press still sets } \\
\text { wider media news agendas, } \\
\text { and shows a strong pro-Tory } \\
\text { imbalance. } \\
\text { - Brexiteer press titles have } \\
\text { stoked up polarisation by } \\
\text { strongly adversarial press } \\
\text { coverage. }\end{array}$ & 0.75 & $\begin{array}{l}\text { Media } \\
\text { support for } \\
\text { democracy }\end{array}$ & 0.5 & $\begin{array}{l}\text { - There some signs that the } \\
\text { political influence of the } \\
\text { strongly partisan press has } \\
\text { slipped as people's sources } \\
\text { of news and opinion have } \\
\text { diversified. } \\
\text { - Post-Leveson press } \\
\text { behaviour has slightly } \\
\text { improved, from a low } \\
\text { base. Rights of redress } \\
\text { for inaccuracy and privacy } \\
\text { invasions are still weak. }\end{array}$ \\
\hline
\end{tabular}




\begin{tabular}{|c|c|c|c|c|}
\hline $\begin{array}{r}\text { Have substantial threats } \\
\text { or problems to democratic } \\
\text { quality emerged in this area? }\end{array}$ & $\begin{array}{l}\text { Problems/ } \\
\text { threats } \\
\text { score }\end{array}$ & $\begin{array}{l}\text { Institutional } \\
\text { or topic area }\end{array}$ & $\begin{array}{l}\text { Gains/ } \\
\text { positives } \\
\text { score }\end{array}$ & $\begin{array}{l}\text { Have positive and } \\
\text { substantial pro- } \\
\text { democratisation trends } \\
\text { occurred in this area? }\end{array}$ \\
\hline $\begin{array}{r}\text { - Fake news and manipulation } \\
\text { of information chains, plus } \\
\text { libertarian hangovers in major } \\
\text { platform companies have } \\
\text { dramatised major lags and } \\
\text { deficiencies in the regulation } \\
\text { of online spaces in the public } \\
\text { interest. } \\
\text { - Any new medium of } \\
\text { communication can give } \\
\text { greater prominence and } \\
\text { efficacy to harmful social } \\
\text { actors, especially where } \\
\text { regulation lags behind current } \\
\text { social practices (as with trolling, } \\
\text { hate speech, and other anti- } \\
\text { social communication). }\end{array}$ & 0.75 & $\begin{array}{l}\text { Social media } \\
\text { support for } \\
\text { democracy, } \\
\text { and civic } \\
\text { participation }\end{array}$ & 0.75 & $\begin{array}{l}\text { - The depth, speed and } \\
\text { efficacy of ordinary citizens' } \\
\text { vigilance over their elected } \\
\text { representatives, government } \\
\text { and the public services has } \\
\text { clearly improved. } \\
\text { - 'Clicktivism' is widely } \\
\text { practised and seems to } \\
\text { have enhanced (rather than } \\
\text { reduced) other forms of civic } \\
\text { participation. }\end{array}$ \\
\hline $\begin{array}{l}\text { - Brexit threatens to produce a } \\
\text { tidal wave of executive action/ } \\
\text { statutory instrument changes } \\
\text { with only reduced levels of } \\
\text { parliamentary scrutiny. }\end{array}$ & 0.25 & $\begin{array}{c}\text { The } \\
\text { democratic } \\
\text { effectiveness } \\
\text { of } \\
\text { Parliament }\end{array}$ & 0.75 & $\begin{array}{l}\text { - The return of a 'hung' } \\
\text { parliament in 2017, after } \\
\text { only two years of majority } \\
\text { government has increased the } \\
\text { influence of Parliament and } \\
\text { of MPs. } \\
\text { - Select committees in the } \\
\text { Commons have grown in } \\
\text { influence, and some analysts } \\
\text { argue that bill committees } \\
\text { are not as weak as previously } \\
\text { thought. }\end{array}$ \\
\hline $\begin{array}{r}\text { The upper chamber of the } \\
\text { legislature is completely } \\
\text { unelected. } \\
\text { - Appointments are often linked } \\
\text { to party donations and leaders' } \\
\text { use of patronage. } \\
\text { - The Lords did not curb the } \\
\text { Conservative-Liberal Democrat } \\
\text { government (2010-15). }\end{array}$ & 1.0 & $\begin{array}{l}\text { The House of } \\
\text { Lords }\end{array}$ & 0.5 & $\begin{array}{l}\text { - The Lords has restrained } \\
\text { Tory governments since } 2015 \text {, } \\
\text { forcing significant moderating } \\
\text { re-thinks on welfare and Brexit } \\
\text { issues. }\end{array}$ \\
\hline $\begin{array}{r}\text { - The UK's 'homeland security' } \\
\text { apparatus has greatly } \\
\text { expanded in areas that } \\
\text { seem to be little covered by } \\
\text { parliamentary scrutiny. } \\
\text { - Parliamentary scrutiny of UK } \\
\text { military actions overseas (for } \\
\text { example, bombing in Syria and } \\
\text { drone assassinations of alleged } \\
\text { terrorists) remains very weak. }\end{array}$ & 0.5 & $\begin{array}{c}\text { Civilian } \\
\text { control of } \\
\text { the military, } \\
\text { police, } \\
\text { homeland } \\
\text { security and } \\
\text { intelligence }\end{array}$ & 0.5 & $\begin{array}{l}\text { - Since August } 2013 \\
\text { Parliament has perhaps had } \\
\text { greater de facto (if not de } \\
\text { jure) control over the Prime } \\
\text { Minister's use of war powers. } \\
\text { - The Intelligence and Security } \\
\text { Committee under Dominic } \\
\text { Grieve has become more } \\
\text { effective and disclosure about } \\
\text { (long) past intelligence service } \\
\text { activities has improved a little. }\end{array}$ \\
\hline
\end{tabular}




\begin{tabular}{|c|c|c|c|c|}
\hline $\begin{array}{l}\text { Have substantial threats } \\
\text { or problems to democratic } \\
\text { quality emerged in this area? }\end{array}$ & $\begin{array}{l}\text { Problems/ } \\
\text { threats } \\
\text { score }\end{array}$ & $\begin{array}{l}\text { Institutional } \\
\text { or topic area }\end{array}$ & $\begin{array}{l}\text { Gains/ } \\
\text { positives } \\
\text { score }\end{array}$ & $\begin{array}{l}\text { Have positive and } \\
\text { substantial pro- } \\
\text { democratisation trends } \\
\text { occurred in this area? }\end{array}$ \\
\hline $\begin{array}{r}\text {. Specific severe policy } \\
\text { disasters (for example, } \\
\text { Iraq 2003-10, Afghanistan } \\
\text { 2007-12, Libya 2013, Universal } \\
\text { Credit, defence planning, } \\
\text { Brexit delays, and the Grenfell } \\
\text { catastrophe) have highlighted } \\
\text { enduring and widespread } \\
\text { failures in central government. } \\
\text { - The overly deep enforcement } \\
\text { of austerity and its over- } \\
\text { long maintenance increased } \\
\text { Whitehall's poor grasp on its } \\
\text { cumulative adverse effects, } \\
\text { and created widespread } \\
\text { administrative malaise. } \\
\text { - This in turn helped fuel Brexit } \\
\text { populism. }\end{array}$ & 0.75 & $\begin{array}{l}\text { Effective core } \\
\text { executive - } \\
\text { the apex of } \\
\text { governance }\end{array}$ & 0 & $\begin{array}{l}\text { - The return to a hung } \\
\text { parliament in } 2017, \text { plus intra- } \\
\text { party divisions over Brexit, } \\
\text { and the failure to develop any } \\
\text { government and opposition } \\
\text { joint working on it, created } \\
\text { party management and } \\
\text { legislative problems that were } \\
\text { debilitating and unfamiliar } \\
\text { for No. } 10 \text {, ministers and } \\
\text { the Whitehall apparatus to } \\
\text { manage. }\end{array}$ \\
\hline $\begin{array}{l}\text { - Austerity effects have } \\
\text { contributed to a loss of } \\
\text { core institutional capacity, } \\
\text { exemplified by the crisis of } \\
\text { light-/no-touch regulation } \\
\text { around Grenfell. }\end{array}$ & 1 & $\begin{array}{l}\text { Civil service } \\
\text { and public } \\
\text { services }\end{array}$ & 0.25 & $\begin{array}{l}\text { - It is hard to see signs } \\
\text { of any positive changes } \\
\text { or improvements, except } \\
\text { perhaps some partial } \\
\text { protection of NHS services via } \\
\text { inflation increases. }\end{array}$ \\
\hline $\begin{array}{r}\text {-A steady stream of fairly } \\
\text { minor corruption or integrity } \\
\text { scandals has occurred. } \\
\text { - UK arms sales remain an area } \\
\text { with major ethical problems } \\
\text { (for example, in supplying arms } \\
\text { clearly used against civilians in } \\
\text { Yemen). }\end{array}$ & 0.5 & $\begin{array}{l}\text { Integrity in } \\
\text { public life }\end{array}$ & 0.5 & $\begin{array}{l}\text { - Past institutional cover- } \\
\text { ups (for example, over } \\
\text { Hillsborough and in } \\
\text { institutions like churches) have } \\
\text { been exposed. } \\
\text { - Some areas of greater } \\
\text { openness show progress (for } \\
\text { example, identifying Persons } \\
\text { with Significant Control of } \\
\text { companies). }\end{array}$ \\
\hline $\begin{array}{r}\text { - Whitehall centralism over } \\
\text { Brexit has engendered } \\
\text { acrimonious battles over the } \\
\text { transfer for EU functions. } \\
\text { - The } 2017 \text { Tory manifesto } \\
\text { threat to the legitimacy of } \\
\text { mayoral elections shows a rash } \\
\text { willingness to jeopardise well- } \\
\text { working democratic institutions } \\
\text { solely for minor partisan } \\
\text { advantage. }\end{array}$ & 0.25 & $\begin{array}{l}\text { Devolution } \\
\text { within } \\
\text { mainland } \\
\text { Britain }\end{array}$ & 1 & $\begin{array}{l}\text { - The strong decentralisation } \\
\text { of powers to Scotland and } \\
\text { Wales since } 2014 \text { have } \\
\text { transferred key functions. } \\
\text { - The changes have also } \\
\text { created a somewhat stronger } \\
\text { inter-governmental process, } \\
\text { with some Supreme Court } \\
\text { overview. } \\
\text { - More powers for the London } \\
\text { mayor and the creation of } \\
\text { new metro/regional mayors } \\
\text { have begun to address the } \\
\text { gross over-concentration } \\
\text { of English governance } \\
\text { powers in Whitehall and the } \\
\text { previous lack of regional-tier } \\
\text { democracy. }\end{array}$ \\
\hline
\end{tabular}




\begin{tabular}{|c|c|c|c|c|}
\hline $\begin{array}{l}\text { Have substantial threats } \\
\text { or problems to democratic } \\
\text { quality emerged in this area? }\end{array}$ & $\begin{array}{l}\text { Problems/ } \\
\text { threats } \\
\text { score }\end{array}$ & $\begin{array}{l}\text { Institutional } \\
\text { or topic area }\end{array}$ & $\begin{array}{l}\text { Gains/ } \\
\text { positives } \\
\text { score }\end{array}$ & $\begin{array}{l}\text { Have positive and } \\
\text { substantial pro- } \\
\text { democratisation trends } \\
\text { occurred in this area? }\end{array}$ \\
\hline $\begin{array}{l}\text { • The partial collapse of } \\
\text { devolution institutions and } \\
\text { arrangements in Northern } \\
\text { Ireland, and the border woes } \\
\text { there over Brexit are worrying. }\end{array}$ & \multirow[t]{2}{*}{1} & \multirow[t]{2}{*}{$\begin{array}{l}\text { Devolution } \\
\text { in Northern } \\
\text { Ireland }\end{array}$} & \multirow[t]{2}{*}{0.25} & \multirow[t]{2}{*}{$\begin{array}{l}\text { - So far there have not been } \\
\text { major adverse consequences } \\
\text { of the suspension of devolved } \\
\text { government. }\end{array}$} \\
\hline $\begin{array}{l}\text { • The DUP providing } \\
\text { 'confidence and supply' to } \\
\text { the May government since } \\
2017 \text { puts a question mark } \\
\text { over Westminster's impartiality } \\
\text { between Northern Ireland } \\
\text { communities and parties. }\end{array}$ & & & & \\
\hline $\begin{array}{r}\text { Drastic austerity measures } \\
\text { have extensively hollowed } \\
\text { out local services and } \\
\text { administrative competencies. }\end{array}$ & \multirow[t]{2}{*}{1} & \multirow[t]{2}{*}{$\begin{array}{l}\text { Decentral- } \\
\text { isation to } \\
\text { communities } \\
\text { and public } \\
\text { services }\end{array}$} & \multirow[t]{2}{*}{0} & \multirow{2}{*}{$\begin{array}{l}\text { - No easing of adverse } \\
\text { financial pressures on English } \\
\text { local government has yet } \\
\text { occurred. } \\
\text { - Social care for the elderly } \\
\text { was a central issue in the } \\
2017 \text { election but funding } \\
\text { arrangements remain } \\
\text { unsustainable, severely } \\
\text { squeezing all other forms of } \\
\text { municipal spending. }\end{array}$} \\
\hline $\begin{array}{r}\text { The fiscal position of local } \\
\text { authorities under austerity } \\
\text { policies has become } \\
\text { unsustainable. } \\
\text { - The value of local democratic } \\
\text { politics has been eroded as } \\
\text { it becomes solely about the } \\
\text { management of unsustainable } \\
\text { cutbacks. }\end{array}$ & & & & \\
\hline $\begin{array}{r}\text { - Government ministers have } \\
\text { regularly proposed fees or } \\
\text { restricted eligibility criteria for } \\
\text { people to access administrative } \\
\text { tribunals and other channels for } \\
\text { citizen redress. }\end{array}$ & \multirow[t]{2}{*}{0.75} & \multirow[t]{2}{*}{$\begin{array}{l}\text { Rule of law } \\
\text { and access to } \\
\text { justice }\end{array}$} & \multirow[t]{2}{*}{0.5} & \multirow{2}{*}{$\begin{array}{l}\text { - The Supreme Court has } \\
\text { been active in defending } \\
\text { access to legal aid, and } \\
\text { has begun to play a more } \\
\text { important and active role in } \\
\text { protecting citizens' rights } \\
\text { against Whitehall, shaping } \\
\text { how devolution arrangements } \\
\text { operate, and how Brexit is } \\
\text { accomplished. }\end{array}$} \\
\hline $\begin{array}{l}\text { - The very restricted availability } \\
\text { of legal aid plus high legal } \\
\text { costs shut out most people } \\
\text { from effective access to the } \\
\text { courts and legal redress. }\end{array}$ & & & & \\
\hline $\begin{array}{r}\text { - Proposals for mass } \\
\text { surveillance and cracking down } \\
\text { on unauthorised access to } \\
\text { official papers are recurringly } \\
\text { brought forward by ministers } \\
\text { or advocated by intelligence } \\
\text { agencies. }\end{array}$ & 0.5 & $\begin{array}{l}\text { Civil and } \\
\text { political } \\
\text { rights }\end{array}$ & 0.5 & $\begin{array}{l}\text { - Past Conservative threats } \\
\text { to the } 1998 \text { Human Rights } \\
\text { Act by introducing a 'British } \\
\text { Bill of Rights' or even leaving } \\
\text { the EHRC court in Strasbourg } \\
\text { appear to have receded. }\end{array}$ \\
\hline
\end{tabular}




\begin{tabular}{|c|c|c|c|c|}
\hline $\begin{array}{l}\text { Have substantial threats } \\
\text { or problems to democratic } \\
\text { quality emerged in this area? }\end{array}$ & $\begin{array}{l}\text { Problems/ } \\
\text { threats } \\
\text { score }\end{array}$ & $\begin{array}{l}\text { Institutional } \\
\text { or topic area }\end{array}$ & $\begin{array}{l}\text { Gains/ } \\
\text { positives } \\
\text { score }\end{array}$ & $\begin{array}{l}\text { Have positive and } \\
\text { substantial pro- } \\
\text { democratisation trends } \\
\text { occurred in this area? }\end{array}$ \\
\hline $\begin{array}{l}\text { • The Brexit decision as } \\
\text { implemented in the } 2018 \mathrm{EU} \\
\text { Withdrawal Act means that the } \\
\text { EU's Charter of Rights is no } \\
\text { longer applicable within the } \\
\text { UK. Executive orders made } \\
\text { under this law may radically } \\
\text { reduce previous rights in areas } \\
\text { like employment. }\end{array}$ & 0.75 & $\begin{array}{l}\text { Economic } \\
\text { and social } \\
\text { rights }\end{array}$ & 0.5 & $\begin{array}{l}\text { - Fees for employment } \\
\text { tribunal access have been } \\
\text { struck down by the Supreme } \\
\text { Court. } \\
\text { - Some 'gig economy' } \\
\text { workers' rights have been } \\
\text { protected by legal decisions. }\end{array}$ \\
\hline $\begin{array}{r}\text { - Brexit populism apparently } \\
\text { fuelled a decline in toleration } \\
\text { and increased political rancour. } \\
\text { • The prolonged delay in } \\
\text { developing a clear Brexit } \\
\text { position gave the lie to } \\
\text { previous assumptions } \\
\text { about the 'efficiency' or } \\
\text { 'effectiveness' of the UK's } \\
\text { democratic government. }\end{array}$ & 1 & $\begin{array}{l}\text { The UK's } \\
\text { influence } \\
\text { on the } \\
\text { development } \\
\text { of democracy } \\
\text { worldwide }\end{array}$ & 0.25 & $\begin{array}{l}\text { - Some moves in the UK to } \\
\text { more socially liberal attitudes } \\
\text { can be seen as contributing } \\
\text { to similar shifts elsewhere (for } \\
\text { example, in Ireland on divorce } \\
\text { and abortion, and in Australia } \\
\text { on legalising gay marriage). }\end{array}$ \\
\hline
\end{tabular}

It is also useful to consider the different topics and areas above in terms of those showing the strongest pro-democracy trends versus those showing the greatest cumulation of adverse developments. Figure 2 shows just the numeric scores for each topic area, showing that negative scores overall outweigh positive.

Figure 3 lists them in order, with the highest net positive scores at the top and the worst net negative scores at the bottom of the table. The clearly positive areas cover devolution within Britain, the roles of Parliament and political parties - shown with green shaded backgrounds. Electoral integrity and the role of social media and civic participation also show strengths, but also some major problems of the digital era. A whole raft of areas have clear negative scores, shown shaded in light pink. In the middle of the table these categories are somewhat offset by equivalent positive changes, but at the bottom of the table they are not.

Overall Figures 2 and 3 makes for somewhat grim reading. In many different respects the UK's liberal democracy is still historically flawed or eroding under modern trends, and these areas outweigh the undoubted positives still occurring, often begun in earlier periods. 
Figure 2: Positive and adverse developments in different areas of the UK's democratic life - summarised
$-1$
$-0.75$
$-0.5$
$-0.25$
0
0.25
0.5
$0.75 \quad 1$

Voting system fairness across parties

Electoral integrity and participation

The democratic roles of political parties

The interest group process

Media support for democracy

Social media support for democracy, and civic participation

The democratic effectiveness of Parliament

The House of Lords

Civilian control of the military, police, homeland security and intelligence

Effective core executive the apex of governance

Civil service and public services

Integrity in public life

Devolution within mainland Britain

Devolution in Northern Ireland

Decentralisation to communities and public services

Rule of law and access to justice

Civil and political rights

Economic and social rights

The UK's influence on the development of democracy worldwide

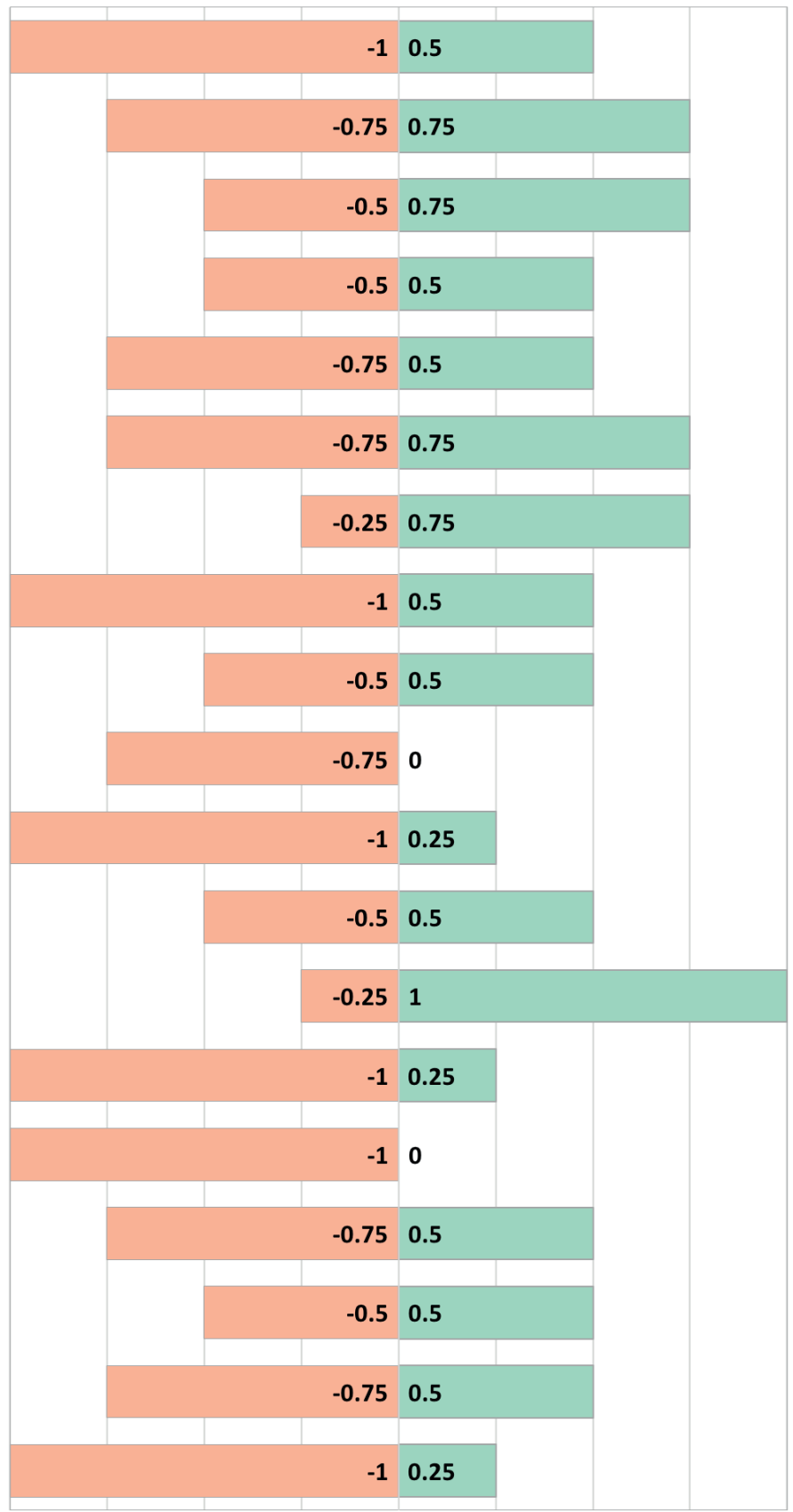

Problems/threats score $\square$ Gains/positive score 
Figure 3: The balance of scores for positive and adverse developments in different areas of the UK's democratic life

\begin{tabular}{|c|c|c|c|}
\hline Topic or institutional area & $\begin{array}{c}\text { Net } \\
\text { 'democratic } \\
\text { improvement' } \\
\text { score }\end{array}$ & $\begin{array}{c}\text { Score for } \\
\text { positive } \\
\text { developments }\end{array}$ & $\begin{array}{c}\text { Score for } \\
\text { adverse } \\
\text { developments }\end{array}$ \\
\hline Devolution within mainland Britain & +0.75 & 1.0 & -0.25 \\
\hline $\begin{array}{l}\text { The democratic effectiveness of } \\
\text { Parliament }\end{array}$ & +0.5 & 0.75 & -0.25 \\
\hline The democratic role of political parties & +0.25 & 0.75 & -0.5 \\
\hline Electoral integrity and participation & 0 & 0.75 & -0.75 \\
\hline Social media and civic participation & 0 & 0.75 & -0.75 \\
\hline $\begin{array}{l}\text { Civilian control of the military, police } \\
\text { homeland security and intelligence }\end{array}$ & 0 & 0.5 & -0.5 \\
\hline The interest group process & 0 & 0.5 & -0.5 \\
\hline Civil and political rights & 0 & 0.5 & -0.5 \\
\hline Integrity in public life & 0 & 0.5 & -0.5 \\
\hline Media support for democracy & -0.25 & 0.5 & -0.75 \\
\hline Rule of law and access to justice & -0.25 & 0.5 & -0.75 \\
\hline Economic and social rights & -0.25 & 0.5 & -0.75 \\
\hline Voting system fairness across parties & -0.5 & 0.5 & -1.0 \\
\hline The House of Lords & -0.5 & 0.5 & -1.0 \\
\hline $\begin{array}{l}\text { UK influence on the development of } \\
\text { democracy worldwide }\end{array}$ & -0.75 & 0.25 & -1.0 \\
\hline Civil services and public services & -0.75 & 0.25 & -1.0 \\
\hline Devolution in Northern Ireland & -0.75 & 0.25 & -1.0 \\
\hline $\begin{array}{l}\text { Effective core executive - the apex of } \\
\text { governance }\end{array}$ & -0.75 & 0 & -0.75 \\
\hline $\begin{array}{l}\text { Decentralisation to communities and } \\
\text { public services }\end{array}$ & -1.0 & 0 & -1.0 \\
\hline
\end{tabular}




\section{2}

\section{Counteracting democratic decay}

The UK's mixed, at times even shaky, record of recent changes is just the latest chapter in a series of evolving developments that have created a strong domestic tradition on which citizens, politicians and public servants can draw to adapt to new challenges. This is both a considerable strength and a weakness in several masked ways.

As Chapter 1.3 argued, the modern UK state apparatus and elite decision-making cultures still bear many legacies of the lengthy imperial state period - principally manifest in an elite culture (spanning the executive, legislature and the senior judiciary) that disdains any finetuning of democratic control in favour of prioritising the ability of government to govern. From the mid-18th century to the late 1960s, UK Prime Ministers and Cabinets grappled with jointly running a home island state that was constitutionalising and democratising, while also governing colonies overseas that were essentially run in an authoritarian fashion.

In addition, the long survival and adaptability of the 'British political tradition' bred a kind of superiority complex, in which British decision-makers (and many voters too) thought of the UK as a world leader in democratic practices, the home of the 'Mother of Parliaments', and so not in need of any careful introspection about domestic democracy, still less of learning any lessons from overseas.

These attitudes have waned somewhat in influence but they remain powerful. The currently weak global situation of liberal democracies makes maintaining either stance highly inappropriate, and dangerously complacent. Taking democratic reform in the UK seriously from 2018 onwards is likely to involve three main changes, discussed in turn below. First, the UK's imminent departure from the European Union may (or may not) mark the end of a two decades' long process of the UK's politics and constitutional set-up 'Europeanising'. Does Brexit mean the loss of this potent 'modernisation' pathway for future development? Second, our analysis re-confirms that liberal democratic governance is far more complex than many previous analyses have allowed. In addition to the big and obvious macroinstitutions of a democratic state, there are also a host of micro-institutions whose set-up and operations can make a major difference to how the overall political system operates. Finally, the rise of debased semi-democracies, plus extensive backsliding amongst many states previously thought of as securely within the liberal democratic camp, shows the need for a radical reappraisal of the difficulties of sustaining liberal democratic processes on a pathway of growth and positive development. 


\section{(i) Losing the 'Europeanisation' narrative for modernising British democracy}

The 2016 Brexit referendum vote has already marked a key turning point in the UK's political system. Its significance also extends beyond the economic and governance changes that are directly involved to its likely cultural and symbolic consequences. One of these may be the disappearance of a previously influential narrative of what has been happening to British democracy, and of a template for where it will go in the years ahead. The advent of the Labour government under Tony Blair in 1997 sparked a whole series of major constitutional changes. Traditionalist critics (like Anthony King in his book The British Constitution) complained that there was no coherent plan behind Labour's changes, that ministers had tinkered with a huge range of institutions without being clear what they were trying to achieve.

There is an alternative interpretation, however, namely that from 1997 to 2016 the UK was strongly Europeanising, falling into line with patterns of political development that were (and still are) common to almost countries across western Europe. The cumulative effect of these changes was to 'normalise' and 'modernise' UK democracy, moving away from past patterns of British exceptionalism and uniqueness compared with neighbouring states. Figure 1 shows some of the most important 'Europeanising' trends over these two decades, and asks whether they are likely to continue post-Brexit.

Can the 'British political tradition' provide an alternative modernisation template to the Europeanisation/ normalisation pathway after exit from the EU in March 2019? Some critics argue that Brexit, plus the SNP push for Scottish independence, plus a prevailing mood of 'anti-politics' distrustful of established elites, mean that the Westminster model has never been more contested. Its 'focus on strong rather than responsive government distances Westminster from citizens', according to Marsh and colleagues. 


\section{Figure 1: Six main 'Europeanisation' trends within the UK 1997-2016, and their likely future prospects}

\section{Main Europeanising trend}

Multi-party politics - with a standard five or six parties across the country, including far right, greens, social democrats, conservatives and liberals.

Coalition or minority governments (in hung parliaments), because no party wins an overall majority.

Proportional representation voting systems - as in Scotland, Wales, and London.

Elected executive mayors (and police and crime commissioners).

Civil rights codified in a constitution or single document - as with UK's Human Rights Act 1998.

Clear constitutional separation of executive from judiciary - as with the creation of UK the Supreme Court and Ministry of Justice.

Shifts of functions to quasi-federal sub-national governments - as with devolution to Scotland and Wales.

\section{Prospects from 2016 on}

The political 'suicides' of the Liberal Democrats (in joining a Tory-dominated government 2010-15) and of UKIP (after Brexit was won) cut back multi-partism in England at the 2017 Westminster elections, but not in the devolved polities or at local level. How long the current focus on the top two-parties will endure is difficult to guess.

Since 2010, only two years have seen a (slender) majority government. But after the Liberal Democrats loss of two-thirds of their voters in 2015, future coalition governments seem unlikely. Minority governments with 'confidence and supply' arrangements seem more likely.

The public's rejection of the Liberal Democrats' doomed 2011 referendum attempt to introduce the alternative vote (AV) electoral system has probably killed off change in this area at a UK level. (Some voting system reform might still happen in Welsh local government.)

Executive mayors have spread incrementally under Labour and Conservative governments, so some further expansion is possible.

The HRA has survived strong Tory mobilisations against it, and looks likely to endure - especially with the UK abandoning the EU's Charter of Fundamental Rights in 2019 as part of Brexit.

Initially opposed by judges and lawyers, the Blair government's stronger separation of executive from the judiciary has been a considerable success. The UK Supreme Court is likely to grow in influence over time.

The UK's devolution arrangements are messy and partial compared to most large European nations, but their successful expansion makes further developments likely in future. 
Nonetheless, given the history of the UK's political evolution, it is not out of the question that Brexit leads to a re-emphasis on British exceptionalism, a renewed emphasis on traditional or historical themes in a 'back to the future' mode. Echoes of such a position are strongly present amongst Conservative Brexiteers, and powerfully underlie Boris Johnson's (much misquoted) complaint against May's Chequers deal, that: 'We have wrapped a suicide vest around the British constitution - and handed the detonator to [the EU]'. What might be the elements of a resurgence of UK exceptionalism? Some possible pieces are already on the board, including the 2011 referendum rejection of the alternative vote (AV) electoral system as a 'reform' of plurality rule, the revival of two-party dominance (produced by the successive collapses in support for the Liberal Democrat and UKIP) in England, and the re-creation of some mass membership parties. Combined with the cultural backlash that Brexit represents, especially if a charismatic leader like Johnson becomes Prime Minister at any stage, it is conceivable that these and other developments may bring the Europeanisation trends above to a juddering halt, so that the UK's previous 'exceptionalism' from European democratic patterns continues indefinitely.

The final scenario is that Europeanisation trends peter out over time, but that the challenges posed by Brexit and some radically new problems (like adapting to digital-era politics and the growth of social media) mean that the UK's political system stagnates, or deadlocks, or moves randomly from one uncertain situation to another, with no coherent map or narrative of future development. 'Taking back control' of economic regulation, trade, immigration and much more is the biggest change in UK governance for half a century. It has already produced enduring crises for the party system, Parliament and the core executive, with uniquely contested governance over critical issues, and a rapidly changing political landscape. There may well be more of the same ahead.

\section{(ii) Micro-institutions matter, so fix small defects}

Past history offers many examples where social and political scientists have been influenced by developments in the STEMM disciplines (science, technology, engineering, mathematics and medicine) in how they seek to understand society. Of course, no direct read-across can occur - but the methods involved in STEMM research often inspire social scientists to do something similar, if they can. For instance, in a range of areas now, 'big data' and the application of artificial intelligence are likely to have extensive consequences for social science methods, just as they already have in STEMM and business research. And the models that STEMM scientists develop often furnish influential analogies - especially in understanding how complex causation of events can work.

In terms of causation analogies, the modern development of genetics research has been most recently influential. A decade or more ago geneticists confidently anticipated that they would be able to 'explain' the onset of many different human conditions and diseases by identifying small numbers (ten to a dozen) of genetic markers in the human genome - and that this in turn would open the way to potential remedies at the genetic level. The first 
part of these expectations has been confounded however by the far greater complexity of genetic conditioning than anticipated. The modern picture is that:

'Many small genetic changes are involved in the expression of a single trait, and each change is correlated with a tiny tweak to the human form. To find the tiny effects that individual letters of the genome have on traits, disease, and behavior, you need enormous data sets to separate signal from noise.'

In particular, although there are some critically important 'main effect' genes, how they operate turns out to be fundamentally shaped or conditioned by many other 'small effects' genes that often switch on or off, or radically modify, the impacts of the 'main' genes. The result is a far more complex and holistically shaped set of influences, requiring the most careful analysis to unpick hundreds of different effects operating simultaneously.

This picture is interesting when set against the far simpler causal patterns that are still being explored in political science, economics and sociology. Most research about the pre-conditions for and influences shaping liberal democracies' development still focuses on some tens or dozens of macro-institution variables - such as the kind of electoral system being used, the number of parties in the party system, the level of 'consensus' in legislatures or executive government, or the fiscal decentralisation of government. Much modern research is still just about trying to quantify macro-institution variables' effects more precisely (with more statistical controls), or to understand their operation in more qualitative ways. But a relatively small causal repertoire is still being discussed.

The approach we have adopted here is informed by a different approach, one that assigns a lot of significance to multiple factors interacting in highly complex causal nets. To start with, creating and maintaining any state is a not a simple thing. And controlling that apparatus in liberal democratic ways greatly increases that complexity. It involves meeting many different necessary conditions, all at the same time. These inescapable linkages justify the approach adopted here, of making an in-depth assessment of the quality of the UK's democratic life across multiple different topic areas.

If semi-democracies have taught us anything it is that a genuinely democratic polity is constructed both from a small set of macro-institutions (such as a voting system, or a Parliament), plus dozens or even hundreds of different micro-institutions (for example, sets of rules governing which parties or candidates can stand for elections, or how politically balanced any state-controlled media must be between parties). Micro-institutions often play complex roles, some switching on or off the effects of macro-institutions, and others changing radically how macro-institutions operate. Micro-institutions are small-scale rules and regulations, or minor cultural practices. They often sit well outside the scope of any formal 'constitution', instead lurking in the detailed supplementary practices or mores that grow up around how macro-institutions operate. They are also often found in administrative codes that apparently have little direct connection with the macro-institution they shape.

A clear example for the UK concerns Parliament's role in budgeting. Since the English civil war was resolved by restoring the monarchy in 1659, our (uncodified) constitutional law says beyond any doubt that the House of Commons sets the government budget. But a tiny little rule, sitting in the Standing Orders of the House for decade after decade, also says that 
no MP can present any proposal for spending even £1 of public money unless they have a certificate signed by a minister, which is never given. At a stroke this requirement means that only ministers can present a budget, and that Parliament can perhaps cut spending out of it, but can never add in anything new. This is a key foundation for the normal de facto dominance of the government over the House of Commons, no matter what the formal or apparent constitution may say. In principle, of course, a simple majority of MPs could amend the Standing Orders to remove this requirement, but the cultural and attitudinal rethink needed for any such change after so long means that it is not something that ever 'comes up'. And of course, the elite of the top two parties have a joint incentive to keep it in being.

Even in a designed constitution micro-institutions matter a lot. For example, James Maddison designed the US Electoral College as an elite-level safeguard for ensuring that only 'moderate candidates' would reach the Presidency - but the subsequent development of strong parties quickly reduced the College to a constitutional cipher.

We have only just begun to absorb the importance of micro-institutions, so many questions around them are up for discussion - such as how to distinguish one, and (most importantly) count how many there are. Systematically mapping micro-institutions is just beginning, but the relevant numbers within the UK polity are likely to be numerous - on theory grounds alone. The implication of micro-institutions is that many more combinations of 'big' and 'small' institutional arrangements matter than either most quantitative analyses (still testing 'toy models') or institutional theory itself are prepared to admit.

How many combinations might matter in real-life situations though? Suppose that there are three institutions that operate as switches with a range of settings, running in $1 \%$ increments from $0 \%$ (fully off) to 100\% (fully on) for each switch. There would then be 833 different combinations of switch outcomes. Extend this scenario to ten such switches acting at the same time and the number of combinations exceeds two million combinations. If either of these seems unlikely consider that in 2010 in a Commons with eight parties there were only two or three 'minimum winning coalitions' (those with no 'spare' members), of which only the Conservative-Liberal Democrat alliance was judged feasible by elites. By 2017 no minimum winning coalition passed the parties' acceptability tests, and the simplest oneparty minority government formed instead.

It behoves political scientists to be modest, and to admit that as yet we have only 'broad brush' ideas of how macro-variables interact to sustain liberal democracy or not. And we have barely begun to scratch the surface of assessing micro-institutions' significance especially in switching on or off, or altering, how macro-variables operate. It seems clear from our analysis above that many different micro-institutions matter across all the chapters, and that political elites and citizens should take alterations in how they are set up seriously. To best sustain liberal democracy, we need a whole 'swarm' of micro-institutions to operate in supportive and effective ways - and we should not tolerate persistent small defects that corrode overall democratic quality. 


\section{(iii) Reappraising the difficulties of maintaining liberal democracy}

The best way of preventing 'backsliding' in established liberal democracies is to be constantly aware of the difficulties and complexities in maintaining effective political equality and institutional responsiveness. To be sure of moving forwards it seems sensible never to 'rest on your laurels', but instead to maintain a strong focus on making democratic advances - sustaining continuous improvements in how citizens can seek to influence political elites, raising the standards of performance we expect from our institutions, and removing solvable institutional defects, especially the 'legacy' hangovers from past practices that impede current progress.

'All government is an ugly necessity', said G. K. Chesterton.. So there will always be extensive room for debate and deliberation about exactly how continuous democratic advance is to be achieved. Yet it seems clear that in the modern world, states are effectively 'immortal', and are not going to die away, despite the free-market rhetoric of the neo-liberal right or the communitarian dreams of left anarchists or 'deep green' ecologists. As long as states, communities and the need to make collective choices endure, then the relevance of liberal democracy will also.

It is surely also long overdue for liberal democrats to reconsider the quietist stance of recent decades, where positively advocating free and fair elections and defending human rights and civil liberties have been characterised by many opponents and critics as at best simply ethno-centric (Western-appropriate) reasoning, and at worst a 'cultural colonialist' effort to homogenise the world on globalist lines. Effectively counteracting these now commonplace camouflages for semi-democracies in industrialising countries will involve liberal democracies in questioning their own governance assumptions and unacknowledged cultural limits in far-reaching ways.

Liberal democratic states like the UK and USA can only regain their lost 'city on a hill' soft power influence when they make far clearer to any observer that they are operating majority rule in genuinely fair, frequent and inclusive elections, enacted with commitment, and genuinely seeking widely distributed control of policy-making by the state - mostly by achieving 'consensus' majorities (rather than narrow, partisan sectarianism). A commitment to democratising business and civil society organisations, and increasing social transparency, also needs to underpin the full access to civil and social rights.

Externally, liberal democratic states surely need to show clear concern for their neighbours, for migrants, and for global jeopardy issues, while respecting international law and the autonomy of other legally run states. A dynamic of internal and external democratic advance has already achieved a lot in fields like environmental policy, even where the 'law of the least progressive actor' operates. Extending these lessons to try and better resolve regional and global issues around the inequalities generating large-scale movements of people across state boundaries (apparently now 'fixed for ever') is likely to continue to influence the domestic democratic quality of politics and other liberal democracies. 